\title{
RELASI GENDER PATRIARKI DAN DAMPAKNYA TERHADAP PEREMPUAN HUBULA SUKU DANI, KABUPATEN JAYAWIJAYA, PAPUA
}

\author{
Yanuarius You ${ }^{1}$, Enos H. Rusmansara ${ }^{2}$, Johz Mansoben², dan Agustina Ivone Poli ${ }^{2}$ \\ ${ }^{1}$ Program Doktor Ilmu Sosial, Fakultas Ilmu Sosial dan Ilmu Politik, Universitas Cenderawasih \\ ${ }^{2}$ Dosen Fakultas Ilmu Sosial dan Ilmu Politik Universitas Cenderawasih \\ E-mail:hubula@yahoo.com
}

\begin{abstract}
ABSTRAK. Masyarakat tradisional Hubula Suku Dani di Lembah Baliem Kabupaten Jayawijaya, Papua, membedakan laki-laki dan perempuan di ranah domestik maupun publik. Pembedaan gender ini didasarkan pada tradisi sistem patriarki, yang berdampak terhadap perempuan. Penelitian ini bertujuan untuk menganalisis relasi gender patriarki dan dampaknya terhadap perempuan Hubula Suku Dani. Penelitian ini menggunakan metode deskriptif kualitatif dengan pendekatan studi kasus di masyarakat Hubula Suku Dani di Distrik Aso Lokobal, Kabupaten Jayawijaya, Papua. Data penelitian terdiri dari data primer yang diperoleh langsung dari lapangan melalui observasi lapangan, wawancara mendalam, dan Focus Group Discussion - FGD), dan data sekunder yang diperoleh dari berbagai dokumen yang berkaitan dengan topik penelitian. Data dianalisis dengan teknik deskriptif kualitatif. Hasil penelitian ini menunjukkan bahwa masyarakat Hubula Suku Dani secara kolektif memandang perempuan harus berada dalam posisi subordinasi terhadap laki-laki. Peran publik lakilaki adalah menangani acara adat dan perang, dan peran domestik perempuan adalah mengurus kebun, ternak, rumah tangga serta mengasuh anak. Pembagian peran ini berbasis adat, membentuk struktur sosial fungsional dan melindungi perempuan. Namun, kini perang tidak terjadi, adat memudar, dan laki-laki tidak berfungsi sebagai pencari nafkah. Walau terjadi disfungsionalisme struktural, laki-laki tetap ingin dilayani istri. Dominasi patriarki kian menindas, menimbulkan ketidakadilan gender, dan bermuara pada kekerasan perempuan seperti kekerasan fisik, seksual, emosional, verbal, psikologis, ekonomi, serta intimidasi dan ancaman. Kekerasan perempuan ini bervariasi, namun merata atau membudaya di banyak keluarga Hubula Suku Dani.
\end{abstract}

Kata kunci: Relasi Gender; Sistem Patriarki; Ketidakadilan Gender; Kekerasan Laki-laki atas Perempuan

\section{PATRIARCHAL GENDER RELATION AND THE IMPACT ON HUBULA WOMEN OF DANI TRIBE, JAYAWIJAYA REGENCY, PAPUA}

\begin{abstract}
Tradisional Hubula society of Dani Tribe in Baliem Valley, Jayawijaya Regency, Papua differentiated men and women in domestic and public life. This gender differentation was based on a patriarcal system with impacts on women. This study aims to analyzing the patriarchal gender relation of men and women and its impact on Hubula women of Dani Tribe. It used a descriptive qualitative method with a case study approach in Hubula society of Dani Tribe in Aso Lokobal District, Jayawijaya Regency, Papua. Data used consisted of primary data directly collected through field observation, in-depth interviews and Focus Group Discussion, and secondary data collected from documents related to the research topic. The data were analyzed by a descriptive qualitative technique. Results of the study show that Hubula society of Dani Tribe collectively viewed that women must be subordinate to men. Mens's public roles were to handle customary and war affairs, while women's domestic roles were to take care of field, husbandry, domestic and children affairs. The division of roles was based on customs, establishing the social structure that functionally protected women. However, war no longer occurred, customs faded, and men is no longer able to serve as breadwinners. Despite structural disfungsionalism, men still want to be served by wife. Patriarchal domination is increasingly exploitative, causing gender inequality, and violence against women such as physical, sexual, emotional, verbal, psychological, and economic violence as well as intimidation and threats. These violences varied but are more prevalent among the Hubula families of Dani Tribe.
\end{abstract}

Key words: Gender Relation; Patriarchal System; Gender Inequality; Violence over Women

\section{PENDAHULUAN}

Di era modern seperti sekarang praktik ketidakadilan gender masih sering terjadi di berbagai daerah, termasuk Papua. Berbagai bentuk ketidakadilan gender dalam masyarakat memberikan pembatasan kepada perempuan, yaitu: diskriminasi, eksploitasi, marginalisasi, subordinasi, stereotipe/pelabelan negatif, dan kekerasan terhadap perempuan serta beban kerja lebih berat dan panjang bagi perempuan (Suryadi dan Idris, 2004). Berbagai bentuk ketidakadilan gender ini saling terkait, menimbulkan kekerasan terhadap perempuan, dan mengkristal dalam budaya masyarakat sehingga sulit diluruskan.
Beberapa kisah menyedihkan mengenai nasib kaum perempuan di wilayah Kabupaten Jayawijaya dapat ditemukan dalam Papua Nyawene: Papua Bercerita (Pergumulan Menata Hidup Menuju Papua Tanah Damai dan Adil) (Dale et al., 2014). Paling tidak ada tiga permasalahan hidup yang mengindikasikan beratnya kekerasan yang selama ini dialami oleh banyak perempuan tradisional di wilayah Lembah Baliem Kabupaten Jayawijaya. Pertama, berlipat gandanya beban kerja perempuan di kebun karena laki-laki malas bekerja di kebun dan kerjanya hanya keluyuran ke kota tanpa tujuan dan hasil yang jelas. Istri terpaksa harus mengolah kebun, padahal dulu pekerjaan itu tugas laki- 
laki. Kedua, kurang didengarnya pendapat perempuan dan jika perempuan bersuara, suami main pukul karena dia merasa tersinggung. Ketiga, istri takut punya anak banyak akibat beban kerjanya berlipat ganda tetapi lakilaki tidak bertanggung jawab. Suami tidak mau bekerja tetapi selalu memaksa meminta makan dan hubungan seks. Jika makanan tidak ada di rumah atau istri tidak mau melayani hubungan seks, suami main pukul tanpa merasa malu bahwa dia tidak bekerja dan tidak bertanggung jawab pada keluarga. Ketiga masalah ini menjadi akar utama munculnya kekerasan perempuan di Kabupaten Jayawijaya. Beberapa kasus kekerasan tersebut sudah dilaporkan kepada Lembaga Swadaya Masyarakat (LSM) yang ada di Kabupaten Jayawijaya dan korban kemudian diberi pendampingan untuk melaporkan kasus-kasus kekerasan tersebut kepada pihak berwajib.

Salah satu lembaga yang menangani suara perempuan Papua, khususnya di Kabupaten Jayawijaya, adalah Yayasan Humi Inane (Suara Perempuan-Women's Voice Foundation). Sekarang yayasan ini merupakan lembaga yang memberikan pendampingan kepada kaum perempuan, khususnya para korban kekerasan laki-laki. Lembaga ini memiliki data mengenai berbagai praktik ketidakadilan gender dan kekerasan atas perempuan di wilayah Lembah Baliem, Kabupaten Jayawijaya. Pada tahun 2017 perempuan di wilayah Kabupaten Jayawijaya mengalami banyak kekerasan hingga mencapai 411 kasus. Direktur Humi Inane (Suara Perempuan), Margaretha Wetipo, mengaku bahwa data kekerasan atas perempuan setiap tahun tidak stabil, ada saatnya naik dan turun. Misalnya, kekerasan atas perempuan pada tahun 2016 mencapai 224 kasus, sedangkan pada tahun 2015 mencapai 325 kasus. Perempuan sering mengalami kekerasan seksual, kekerasan domestik, penelantaran rumah tangga dan anak, penganiayaan, dan penelantaran ekonomi. Hal ini menunjukkan banyak terjadinya praktik ketidakadilan gender yang dialami oleh perempuan, yang bermuara pada kekerasan laki-laki atas perempuan Hubula Suku Dani, Distrik Asolokobal, Kabupaten Jayawijaya. Perempuan di wilayah tersebut sering mengalami kekerasan fisik dan psikis, dan bentuk yang paling menonjol adalah kekerasan seksual (Cepos, 28-11-2017).

Hubungan antara gender dan kekerasan itu kompleks. Peran-peran maupun perilaku berbeda dari lakilaki dan perempuan, anak-anak maupun orang dewasa, dibentuk dan diperkuat oleh norma-norma gender di dalam masyarakat (WHO, 2009). Salah satu jenis kekerasan paling serius dan dominan terhadap perempuan dalam masyarakat adalah kekerasan domestik (Hoven, 2001). Menurut Njezula (2006), kekerasan domestik terjadi apabila seseorang, dalam hal ini suami, dalam hubungan dengan istrinya, menggunakan cara yang keras dan melecehkan untuk mempertahankan kekuasaan dan kontrol atas istrinya yang tidak berdaya.

Kekerasan perempuan banyak terjadi di Papua dalam bentuk KDRT seperti a) kekerasan fisik berupa pemukulan dan penganiayaan, anggota tubuh dilukai/ dipotong dengan senjata tajam (parang/ golok), dan disiram bahan bakar dan disulut api/ dibakar; b) kekerasan psikis suami atas isteri dengan modus pembatasan ruang gerak, ancaman, caci maki, hinaan dan kekerasan seksual; c) kejahatan perkawinan berbentuk poligami dan perselingkuhan meluas dan meningkat jumlahnya; d) pembiaran alkoholisme, judi, pornografi, dan prostitusi; serta e) beban kerja berlapis, kekerasan atas nama mas kawin, dilema mekanisme bayar denda dan hak waris perempuan. Kekerasan berupa KDRT sering terjadi karena suami merasa berhak memperlakukan istri sesuai keinginan, termasuk melakukan kekerasan kepada istri (Sylvana, et al., 2015).

Praktik dominasi patriarkal dan ketidakadilan gender yang bermuara pada kekerasan perempuan juga terlihat dalam kehidupan domestik dan sosial masyarakat Hubula Suku Dani, Kabupaten Jayawijaya, Provinsi Papua. Masyarakat Hubula adalah bagian dari Suku Dani yang dikenal sebagai masyarakat tradisional yang kuat. Karakteristik menarik masyarakat ini adalah kuatnya posisi laki-laki, yang menempatkan perempuan pada posisi subordinasi dalam keluarga dan masyarakat. Tulisan ini bertujuan untuk menganalisis relasi gender patriarki dan dampaknya terhadap perempuan dalam kehidupan masyarakat Hubula Suku Dani.

Gender dikonstruksi secara individual, interaksional, dan struktural untuk menciptakan batasan maupun peluang lingkungan yang memberikan manfaat lebih banyak bagi laki-laki dibandingkan perempuan. Perbedaan maskulinitas dan femininitas didasarkan pada status tidak setara, di mana maskulinitas merefleksikan dorongan kuat untuk memperjuangkan otoritas dan kekuasaan yang bermuara pada agresi, sedangkan femininitas sering melibatkan pencarian harmoni dan kesejahteraan komunal (Knoblock, 2008). Dari aspek gender, maskulinitas berada dalam hierarki maskulinitas dalam struktur sosial patriarkal (Jansson, 2017).

Konsep gender melahirkan atau memunculkan dikotomi, sifat, peran, dan posisi yang beragam antara laki-laki dan perempuan (Muthali'in, 2001). Dikotomi ini meliputi sifat maskulin bagi laki-laki dan sifat feminin bagi perempuan, peran publik untuk laki-laki dan peran domestik untuk perempuan, posisi mendominasi bagi laki-laki dan posisi tersubordinasi bagi perempuan. Hal ini merefleksikan sistem patriarki yang menciptakan sistem sosial di mana perempuan seringkali mendapati diri mereka berada dalam posisi subordinat (Mtshiselwa, 2015). Sifat, peran, dan posisi ini saling berkaitan satu sama lain dan sulit dipisahkan.

Dalam fungsionalisme struktural, posisi tradisional melihat identitas antara maskulin dan feminin sebagai hasil dari sosialisasi. Sosialisasi terjadi pada masa kanak-kanak, dimana anak laki-laki dan perempuan belajar perilaku yang pantas bagi jenis kelamin mereka. Maskulinitas mengharuskan ketegasan, aktif, lincah, dan cepat mengambil 
inisiatif, sedangkan femininitas mengharuskan kerja sama, pasif, lembut, dan emosional. Sosialisasi dianggap dapat menyebabkan pembedaan gender ke dalam subyek feminin dam maskulin. Keluarga, media, dan pendidikan berperan penting bagi berlangsungnya proses ini (Walby, 1990).

Menurut Alfred Adler (Rutherford, dalam Chapman dan Rutherford, 2014: 8), relasi-relasi kekuasaan dalam struktur sosial sangat penting dipahami dalam kaitannya dengan maskulinitas dan femininitas. Jika laki-laki tidak mampu mencapai kompromi dan khawatir terlihat lembek atau feminin, kompensasinya adalah agresi keunggulan kelaki-lakian yang berlebihan atas perempuan. Untuk laki-laki, persona maskulin dengan otoritas kuat dicapai dengan merepresi kerapuhan dan ketergantungan. Perempuan menjadi ancaman bagi laki-laki, yang mungkin menyingkapkan kelemahan dan meruntuhkan mitos dan ilusi yang menjadi dasar klaim laki-laki atas superioritas, membentuk ikatan kolektif maskulinitas dengan ornamen kekuasaan dan prestise laki-laki. Teori ini menjelaskan elemen psikoanalisis dari rangkaian maskulinitas yang dikonstruksi secara historis.

Praktik sosial berdasarkan gender cenderung membentuk struktur sosial yang merefleksikan dominasi patriarkal. Dalam struktur sosial ini, laki-laki lebih mendominasi perempuan dalam berbagai urusan, baik dalam kehidupan rumah tangga maupun sosial. Semakin keras dominasi laki-laki terhadap perempuan, semakin kuat tendensi ketidakadilan laki-laki atas perempuan, yang berakibat terjadinya kekerasan perempuan. Dalam sistem patriarkal, perempuan ditempatkan pada posisi subordinasi karena mereka adalah perempuan dan perempuan harus berada di bawah dominasi laki-laki. Patriarki kini menjadi bentuk sentral dan sistematis kontrol laki-laki, yang menjadi penyebab subordinasi perempuan (Isran dan Isran, 2012). Intinya, patriarki bukan hanya menjelaskan bagaimana masyarakat berfungsi dengan kekuasaan dominan laki-laki, tetapi bagaimana laki-laki mengontrol perempuan dalam kehidupan masyarakat (Mashiri, 2013).

Patriarki adalah sistem di mana perempuan dijadikan tidak terlihat dan kurang berpengaruh. Laki-laki dengan kekuatan, tekanan langsung, atau melalui ritual, tradisi, hukum, bahasa, adat-istiadat, etiket, pendidikan, dan pembagian kerja menentukan peran yang seharusnya bagi perempuan, dan di mana perempuan berada di bawah posisi laki-laki (Erika, 1986). Laki-laki mendominasi, menindas, dan mengeksploitasi perempuan dan mereka dirugikan di berbagai bidang kehidupan sosial.

Habiba et al.. (2016) menjelaskan bahwa patriarki adalah kekuasaan dan kontrol yang kompleks dalam masyarakat yang didominasi oleh laki-laki. Patriarki melembagakan subordinasi, ketergantungan, atau pengan dalan perempuan kepada laki-laki dalam masyarakat (Habiba et al.., 2016). Sistem ini terdiri dari struktur dan praktik sosial di mana laki-laki menindas, mengeksploitasi, dan mengontrol perempuan (Walby, 1990: 21). Laki- laki menggunakan kekuasaannya untuk mengendalikan perempuan dalam ranah publik dan domestik.

Masyarakat patriarkal menetapkan kriteria bagi posisi perempuan yang tidak setara secara struktural dalam keluarga dan masyarakat dengan menetapkan hak-hak yang berbeda di antara laki-laki dan perempuan. Patriarki diciptakan dan dipertahankan melalui norma, nilai, tradisi, dan pemisahan sosial dari peran-peran gender yang ditanamkan dalam keluarga melalui proses sosialisasi jangka panjang (Johnson, 2005). Patriarki dibentuk dalam masyarakat melalui keluarga di mana laki-laki memegang tanggung jawab keluarga sehingga ia memiliki otoritas dalam mengendalikan keluarga (Parker dan Reckdenwald, 2008). Keluarga memainkan peran penting untuk mewariskan norma patriarkal kepada generasi berikutnya.

Menurut Gheaus (2012), laki-laki dan perempuan sebenarnya sama-sama berhak mendapat perlakuan adil, sehingga orang yang mengalami ketidakdilan akibat jenis kelamin, berarti ia korban ketidakadilan gender. Ketidakadilan gender terjadi jika orang bertindak tidak adil karena kebencian atau prasangka buruk terhadap perempuan, sehingga perempuan menjadi korban ketidakadilan hanya karena mereka perempuan. Dominasi patriarkal yang tidak seimbang, tidak proporsional, atau mulai lepas dari fungsi utama hierarki struktur sosial cenderung menimbulkan ketidakadilan gender, yang bermuara pada kasus kekerasan gender. Kekerasan gender adalah ekspresi maskulinitas hegemonik dan terjadi terutama dalam budaya tradisional yang tak mau berubah, di mana laki-laki terdorong oleh emosi seperti kemarahan dan kecemburuan buta (Chowdhury, 2015).

Kekerasan atas perempuan dapat mengambil bentuk seperti dominasi dan kontrol, intimidasi, tekanan dan ancaman (Ashcraft, 2000). Patriarki adalah struktur sosial yang menekan dan menjadikan korban kekerasan domestik menjadi rentan (Chaitali, 2012). Hal ini mendasari risiko perempuan mengalami kekerasan domestik. Menurut Jura dan Bukaliya (2015), kekerasan domestik adalah tindakan melanggar hukum yang mengakibatkan kematian atau luka fisik, seksual atau mental. Kekerasan ini bersifat fisik, seksual, emosional, verbal, psikologis, ekonomi, serta intimidasi dan pelecehan. Kekerasan tersebut merefleksikan pola sikap dan perilaku yang digunakan untuk memperoleh atau mempertahankan kekuasaan dan kontrol laki-laki atas istri sebagai pasangan intimnya.

Perempuan yang mengalami kekerasan fisik, emosional, atau psikologis dari suami mengalami masalah mendalam, namun jika perempuan lain mengalami masalah yang sama, masalah itu memiliki akar sebagai masalah sosial (Ostadhashemi, et al., 2015). Intensitas dan perluasan kekerasan atas perempuan bervariasi di masyarakat yang berbeda. Namun, kekerasan perempuan umumnya dilakukan suami. Menurut Kagou dan Kamgno (dalam Djamba \& Kimuna, 2015), banyak perempuan sering menjaga diri agar tidak melaporkan kekerasan domestik karena takut mendapat pelecehan lebih banyak 
jika suami mendapati istri menuduh mereka. Dalam keadaan itu bicara tentang perilaku pelecehan suami dapat menyebabkan perceraian, kasus yang banyak dihindari perempuan dengan segala pengorbanan karena mereka tidak ingin meninggalkan anak-anak akibat cerai karena jika terjadi perceraian suami pada umumnya memiliki hak memelihara anak-anak.

Di masyarakat patriarkal, suami biasanya memukul istri yang menentang kendalinya sampai ia tunduk. Suami memukul istri untuk menunjukkan kekuasaan dan istri tidak bisa mengancam kekuasaan sebagai suami (Eng et al., 2010). Dengan nilai patriarkal, masyarakat menunjukkan dukungan kuat pada peran gender dominan laki-laki. Pemukulan istri lebih tinggi di dalam keluarga di mana suami menganut ideologi patriarki dan struktur sosial laki-laki mendukung kekerasan atas perempuan (Yodanis, 2004). Masyarakat patriarkal umumnya tidak memberi perempuan kesempatan bersuara melalui ruang diskusi publik.

\section{METODE}

Penelitian ini dilakukan menggunakan metode kualitatif deskriptif dengan pendekatan studi kasus. Penelitian ini dilakukan antara November 2017 sampai April 2018 di tengah masyarakat Hubula Suku Dani (dikenal sebagai Suku Dani) yang tinggal di Kampung Megapura, Aso Tapo, Weima, Hesatun, dan Hepuba, Distrik Aso Lokobal, Kabupaten Jayawijaya, Provinsi Papua. Dalam pengumpulan data, instrumen penelitian ini adalah peneliti sendiri. Sampel penelitian diambil dengan teknik pengambilan sampel purposif (purposive sampling) sesuai dengan tujuan penelitian. Pemilihan informan kunci ditentukan menggunakan teknik efek bola salju (snowball effect), yaitu ketika bertemu informan kunci yang berpengetahuan luas dan kaya pengalaman tentang objek penelitian, informan kunci itulah yang akan memberikan informasi berikutnya tentang informan kunci lain yang mereka kenal dan berpengetahuan luas serta kaya pengalaman tentang objek penelitian. Data dalam penelitian terdiri dari data primer yang diperoleh secara langsung dari lapangan melalui observasi langsung di lapangan, wawancara mendalam, dan Focus Group Discussion - FGD), dan data sekunder yang diperoleh dengan teknik dokumentasi dari berbagai dokumen yang terkait dengan topik penelitian.

Data penelitian yang terkumpul dianalisis dengan teknik kualitatif deskriptif. Menurut Miles dan Huberman (2009), analisis kualitatif dilakukan melalui tiga alur kegiatan secara bersamaan: reduksi data, penyajian data, dan penarikan kesimpulan, masing-masing sesuai dengan tujuan penelitian.

\section{HASIL DAN PEMBAHASAN}

\section{Pembedaan Laki-Laki dan Perempuan}

Masyarakat Hubula Suku Dani memiliki tradisi budaya atau adat yang sangat kuat, ditandai dengan dominasi laki-laki dalam sistem sosial patriarki. Dalam sistem sosial ini pelembagaan budaya patriarki terjadi melalui pelembagaan peran gender di ranah domestik dan publik, posisi dominasi dan subordinasi serta sifat maskulin dan feminin. Pelembagaan tradisi ini membentuk struktur fungsional dan mendukung dominasi patriarkal, yang bermuara pada ketidakadilan gender dan kekerasan atas perempuan. Hal ini memperkuat sistem sosial kemasyarakatan tradisional yang terbentuk, dengan struktur sosial yang fungsional dalam mendukung sistem patriarki. Dalam hal ini, laki-laki memegang kekuasaan atas perempuan, baik di ranah domestik maupun publik.

MasyarakatHubula SukuDani sejak dulu melakukan pembedaan atas laki-laki dan perempuan dalam sistem sosial yang mapan. Mereka dipisah dan dikonstruksi secara sosial, sehingga akhirnya pemisahan jenis kelamin ini diterima masyarakat turun-temurun tanpa protes. Bagi mereka, pemisahan ini adalah bagian dari adat dan harus diterima sebagai kewajiban adat. Pembedaan laki-laki dan perempuan itu dikonstruksi secara sosial berdasarkan adat. Pembedaan perilaku laki-laki dan perempuan diciptakan oleh laki-laki dan perempuan melalui proses sosial budaya yang panjang berbasis adat sendiri. Hal ini sesuai pendapat Oakley (1972) (Fakih, 1996). Jadi, masyarakat Hubula Suku Dani memandang hubungan antara laki-laki dan perempuan menggunakan perspektif gender berbasis adat masyarakat tradisional.

Sejak anak Hubula lahir, mereka langsung dibedakan antara laki-laki dan perempuan. Dalam tradisi fungsionalisme struktural posisi tradisional melihat identitas antara maskulin dan feminin sebagai hasil sosialisasi. Di masyarakat Hubula Suku Dani, sosialisasi terjadi terutama pada masa kanak-kanak, di mana anak laki-laki dan perempuan mulai belajar perilaku yang pantas bagi jenis kelaminnya. Maskulinitas di masyarakat Hubula Suku Dani mengharuskan anak-anak memiliki ketegasan, selalu bersikap aktif, lincah, dan cepat mengambil inisiatif, sedangkan femininitas masyarakat Hubula Suku Dani mengharuskan perempuan dapat bekerja sama, pasif, lembut, dan emosional. Bagi masyarakat Hubula Suku Dani, sosialisasi dianggap menyebabkan pembedaan gender ke dalam subyek feminin dan maskulin, yang dapat diterima dan dilaksanakan dengan baik. Seperti dikemukakan oleh Walby (1990), lembaga keluarga berperan penting bagi berlangsungnya proses sosialisasi semacam itu.

Masyarakat Hubula Suku Dani melakukan pembedaan gender laki-laki dan perempuan berdasarkan harapan yang berbeda dari orangtua dan tetua adat atas anak laki-laki dan perempuan. Ada mitos yang terbentuk dan diyakini benar sejak lama terkait posisi maupun peran lakilaki dan perempuan, dan pelanggaran atas mitos itu diyakini dapat menimbulkan bencana bagi laki-laki atau perempuan maupun keluarga dan masyarakat. Jika memasuki usia dewasa, perempuan tidak boleh memasuki honai tempat kaneke karena hal itu dapat menyebabkan ibu atau anaknya 
tertimpa malapetaka seperti sakit atau meninggal. Mitos ini menunjukkan bahwa peran gender perempuan dalam masyarakat Hubula Suku Dani umumnya memang sudah didefinisikan sesuai dengan keyakinan masyarakat adat tentang hal-hal yang paling membedakan antara laki-laki dan perempuan.

Masyarakat Hubula Suku Dani memandang pentingnya posisi, otoritas, dan peran laki-laki pada urusan publik dibandingkan laki-laki. Di masa lalu, perspektif gender itu dibutuhkan untuk mempertahankan eksistensi masyarakat tradisional. Peran laki-laki dan perempuan perlu dibedakan, khususnya berdasarkan keras dan lembutnya pekerjaan yang harus dilaksanakan. Masyarakat Hubula Suku Dani memahami bahwa laki-laki harus mengambil bagian pekerjaan kasar karena laki-laki itu kuat dan perkasa, sedangkan pekerjaan lembut diberikan kepada perempuan karena mereka lemah dan memerlukan pertolongan. Berdasarkan pertimbangan ini, masyarakat Hubula Suku Dani menetapkan perempuan bertugas mengurus rumah tangga, merawat kebun, dan memelihara babi, sedangkan laki-laki harus bertugas mengurus adat dan perang. Pembagian kerja berbasis gender antara lakilaki dan perempuan dari masyarakat tradisional Hubula Suku Dani tersebut memberikan peluang partisipasi dan ekonomi bagi laki-laki lebih banyak dibandingkan perempuan, demikian pula dalam pencapaian pendidikan, kesehatan dan kelangsungan hidup, serta pemberdayaan politik, sebagaimana dikemukakan Giuliano (2014). Dalam masyarakat Hubula Suku Dani, kesenjangan peluang antara laki-laki dan perempuan tersebut terjadi, di mana laki-laki berspesialisasi bekerja di luar rumah, sedangkan perempuan berspesialisasi melakukan kegiatan di rumah tangga. Pembagian kerja ini menghasilkan pola dan norma yang berbeda tentang posisi, otoritas, dan peran yang tepat bagi perempuan di masyarakat. Inilah awal mula terbentuknya masyarakat patriarkal yang sejak awal menyediakan tempat alami bagi perempuan dalam rumah dan tempat alami bagi laki-laki di luar rumah.

\section{Dilema Subordinasi Perempuan terhadap Laki- Laki Hubula Suku Dani}

Dalam masyarakat Hubula Suku Dani, walau sistem patrilineal tidak adil karena subordinasi perempuan di bawah dominasi laki-laki, jika melindungi kepentingan perempuan, sistem itu ideal dalam upaya menciptakan kesimbangan dan harmoni. Namun, ketika sistem sosial tersebut mulai menimbulkan interaksi yang tidak adil antara laki-laki dan perempuan, dan perempuan tidak lagi mendapat haknya dari laki-laki setelah kewajibannya terpenuhi, sistem tersebut dapat dikatakan tidak fungsional.

Tabel 1. Pembedaan Gender antara Laki-Laki dan Perempuan Hubula Suku Dani (2018)

\begin{tabular}{|c|c|c|c|}
\hline \multirow{2}{*}{ No. } & \multirow{2}{*}{ Indikator } & Laki-Laki & \multirow{2}{*}{$\frac{\text { Perempuan }}{\text { Peran Domestik }}$} \\
\hline & & Peran Publik & \\
\hline 1. & $\begin{array}{l}\text { Honai } \\
\text { Pusat acara adat, } \\
\text { pembuatan strategi } \\
\text { perang \& pelaksanaan } \\
\text { ritual kesuburan }\end{array}$ & $\begin{array}{l}\text { - Memiliki peran, akses dan kontrol mutlak atas } \\
\text { honai adat } \\
\text { - Menangani urusan adat, perang dan kesuburan. } \\
\text { - Melakukan pembicaraan rahasia dan membuat } \\
\text { keputusan }\end{array}$ & $\begin{array}{l}\text { - Perempuan dilarang masuk honai adat tempat } \\
\text { kaneke } \\
\text { - Menangani urusan domestik untuk keperluan di } \\
\text { honai adat } \\
\text { - Mengurus anak laki-laki sebelum ia inisiasi ke } \\
\text { honai adat }\end{array}$ \\
\hline 2. & $\begin{array}{l}\text { Perang } \\
\text { Laki-laki sering perang } \\
\text { untuk menjaga wilayah } \\
\text { dari serangan musuh } \\
\text { atau balas dendam }\end{array}$ & $\begin{array}{l}\text { - Dilatih sejak kecil untuk berani berperang } \\
\text { - Menjaga wilayah perbatasan dari serangan musuh } \\
\text { - Terlibat dalam perang demi balas dendam }\end{array}$ & $\begin{array}{l}\text { - Mengurus rumah tangga selama terjadi perang } \\
\text { - Mengurus kebun dan ternak selama terjadi } \\
\text { perang } \\
\text { - Mengurus anak selama terjadi perang }\end{array}$ \\
\hline 3. & $\begin{array}{l}\text { Kebun } \\
\text { Lahan dikelola suami } \\
\text { dan istri sebagai sumber } \\
\text { makanan utama berupa } \\
\text { ubi-ubian bagi keluarga }\end{array}$ & $\begin{array}{l}\text { - Melakukan ritual kesuburan kebun di honai adat } \\
\text { - Membahas strategi peningkatan kesuburan kebun } \\
\text { - Membuat bedeng untuk dikelola dan dirawat } \\
\text { oleh istri }\end{array}$ & $\begin{array}{l}\text { - Menggali, menanam, merawat, dan memanen } \\
\text { ubi-ubian } \\
\text { - Membawa pulang ubi-ubian dan memasaknya } \\
\text { - Memanen dan menjual hasil kebun ke pasar }\end{array}$ \\
\hline 4. & $\begin{array}{l}\text { Ternak } \\
\text { Ternak babi dipelihara } \\
\text { untuk keperluan adat, } \\
\text { sumbangan saudara } \\
\text { maupun dijual. }\end{array}$ & $\begin{array}{l}\text { - Melakukan ritual kesuburan ternak di honai adat } \\
\text { - Membahas strategi peningkatan kesuburan ternak } \\
\text { - Menyerahkan babi untuk dipelihara oleh istri }\end{array}$ & $\begin{array}{l}\text { - Memelihara babi untuk keperluan adat } \\
\text { - Memelihara babi untuk sumbangan saudara } \\
\text { - Memelihara babi untuk dijual }\end{array}$ \\
\hline 5. & $\begin{array}{l}\text { Rumah Tangga } \\
\text { Urusan perabot, } \\
\text { perawatan rumah } \\
\text { sampai penyiapan } \\
\text { makanan bagi keluarga. }\end{array}$ & $\begin{array}{l}\text { - Diskusi dan menunggu datangnya makanan di } \\
\text { honai } \\
\text { - Tidak mau terlibat dalam menangani urusan } \\
\text { rumah tangga } \\
\text { - Menurut adat, segala urusan rumah tangga } \\
\text { ditangani istri }\end{array}$ & $\begin{array}{l}\text { - Mengurus perabot rumah } \\
\text { - Membersihkan dan merawat rumah } \\
\text { - Menyiapkan makanan bagi keluarga }\end{array}$ \\
\hline 6. & $\begin{array}{l}\text { Pengasuhan Anak } \\
\text { Kegiatan membesarkan } \\
\text { dan mendidik anak agar } \\
\text { anak-anak memahami } \\
\text { norma dan nilai adat }\end{array}$ & $\begin{array}{l}\text { - Menghindari pamali terkencingi anak sebelum } \\
\text { haid/inisiasi } \\
\text { - Membiarkan anak perempuan diajari ibunya } \\
\text { - Melatih anak laki-laki untuk berani berperang } \\
\text { - Melibatkan anak laki-laki dalam pembicaraan di } \\
\text { honai }\end{array}$ & $\begin{array}{l}\text { - Merawat dan membesarkan anak perempuan } \\
\text { jauh dari honai } \\
\text { - Merawat dan membesarkan anak laki-laki } \\
\text { sebelum inisiasi } \\
\text { - Mengajari anak agar dapat membantu kerja di } \\
\text { kebun }\end{array}$ \\
\hline
\end{tabular}


Ini awal lahirnya gejolak di dalam sistem sosial patrilineal yang tidak lagi bisa menciptakan keseimbangan dan harmoni. Kegagalan struktur fungsional terjadi bila ada masalah sebagai sebab kegagalan fungsi laki-laki dalam struktur yang ada, terutama dalam interaksi ideal berbasis adat terhadap perempuan.

Dengan otoritas yang diberikan adat kepada lakilaki, idealnya harmoni di dalam keluarga dapat tercapai melalui pembagian tanggung jawab suami dan istri yang dapat melahirkan rasa tenang pada keduanya. Harmoni dan ketenangan dari keluarga tradisional bisa terjadi sebagai akibat dari adanya pemilahan peran dalam kehidupan berbasis jenis kelamin (Suryadi dan Idris, 2004: 51-53). Selama fungsi patrilinealisme terlaksana dengan baik sesuai dengan semangat awal tradisi, fungsi sosial dapat dipertahankan. Namun, dalam kehidupan masyarakat Hubula Suku Dani, fungsi-fungsi sosial patriarki yang ideal semakin banyak tidak terlaksana secara baik seiring dengan lunturnya tanggung jawab laki-laki dalam memenuhi kewajiban kepada istrinya, baik dalam ranah domestik maupun publik.

Hasil penelitian menunjukkan temuan menarik bahwa masyarakat Hubula Suku Dani sejak dulu sudah mengembangkan konstruksi sosial yang didasarkan pada pembedaan laki-laki dan perempuan berbasis adat. Pembedaan ini pada prinsipnya didasarkan pada sakralitas honai adat, perbedaan sosialisasi antara laki-laki dan perempuan, pemisahan honai untuk laki-laki dan ebe'ai untuk perempuan, dan pembagian peran publik untuk laki-laki dan peran domestik untuk perempuan. Di masyarakat Hubula Suku Dani, peran publik laki-laki adalah menangani perang dan kesuburan, baik kebun atau ternak, sedangkan peran domestik perempuan adalah mengelola kebun, memelihara ternak, dan mengurus rumah tangga serta merawat, membesarkan dan mendidik anak. Di masyarakat tradisional seperti ini, konstruksi sosial dan pembagian peran era tradisional tersebut membentuk struktur sosial yang bersifat fungsional dan dominasi patriarki yang terbentuk juga bersifat melindungi perempuan.

Seiring dengan perkembangan masyarakat dan persentuhan dengan budaya masyarakat Barat yang lebih maju, kebiasaan perang mulai banyak berkurang dan laki-laki tidak memiliki peran dominan dalam pembuatan keputusan perang. Pada masa damai, idealnya laki-laki masih dapat melaksanakan peran bagian kesuburan untuk mengelola kebun dan memelihara ternak. Namun, dengan dorongan kuat di kalangan laki-laki untuk mencari uang, sebagian besar laki-laki semakin enggan berkebun, khususnya untuk membuat bedeng. Akibatnya, banyak lahan terbengkalai dan tidak bisa dipelihara oleh perempuan. Pada tingkat lebih tinggi, transisi modernisasi tersebut menyebabkan terbentuknya struktur disfungsional di mana dominasi patriarki menjadi tidak relevan lagi karena makin banyak laki-laki tidak memiliki basis ekonomi yang memadai untuk membangun otoritas kepemimpinan atas istri. Jika istri menerima dominasi tersebut, sebagian besar dari mereka akan mengalami dilema: di satu sisi, mereka menurut adat harus selalu mematuhi suami, tetapi di sisi lain, suami tidak lagi berfungsi sebagai pencari nafkah. Di sini terbentuk ruang terbuka bagi terjadinya ketidakdilan gender, yang akhirnya bermuara pada berbagai bentuk kekerasan suami atas istri.

Saat ini laki-laki Hubula semakin tidak mampu melaksanakan fungsi secara optimal sebagai pencari nafkah. Dulu suami berperan menyiapkan bedeng lahan untuk ditanami dan dirawat istri. Saat ini peran tersebut tidak dapat terlaksana sama sekali karena suami malas,

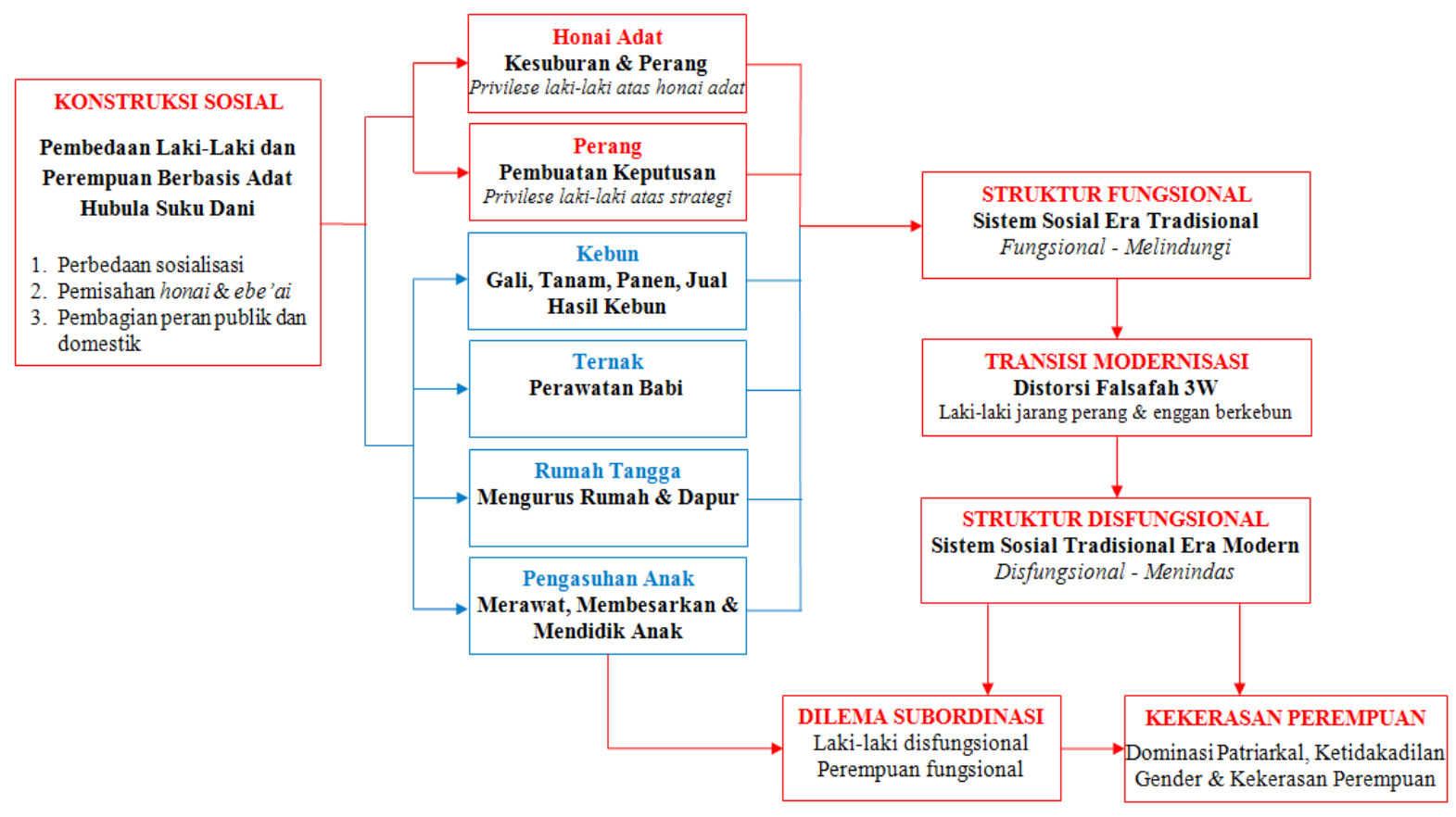

Gambar 1. Hubungan Laki-Laki dan Perempuan dalam Perspektif Laki-Laki Hubula Suku Dani 
tidak bekerja, dan hidupnya mengandalkan kerja istri. Jika di rumah tidak ada makanan sama sekali, mereka menggunakan otoritas adat untuk memaksakan kehendaknya kepada istri dan makanan tetap harus terhidang. Jika dulu istri menghormati suami, saat ini mereka berani bersikap, berkata dan berbuat keras pada suami jika peran pencari nafkah tidak terlaksana dengan baik. Jadi, ada ketimpangan laki-laki dan perempuan dalam mengurus rumah tangga, kebun, dan babi. Suami tak mau membantu istri sama sekali, sedangkan istri terus ditekan dengan adat untuk selalu memenuhi keinginan suami, walau dengan kekerasan.

Hasil penelitian banyak menunjukkan kasus keluhan perempuan terhadap disfungsionalisme laki-laki dalam sistem sosial tradisional berbasis patriarki. Di satu sisi, laki-laki secara adat masih menempati posisi dominan dalam pembuatan keputusan, baik di ranah domestik maupun publik. Namun, di sisi lain, mereka tidak banyak atau bahkan tidak mau terlibat dalam fungsi tradisional, baik dalam urusan adat maupun kebun bersama istri. Hal ini terjadi karena adanya tendensi laki-laki Hubula Suku Dani mulai terpengaruhi oleh gaya kehidupan perkotaan, lalu mereka lebih sering pergi ke kota untuk bekerja atau untuk urusan lain yang tidak jelas, dan akibatnya mereka melupakan atau tidak melaksanakan fungsi pencari nafkah dalam lingkup sistem tradisional di sukunya. Patriarki sebagai sistem yang terdiri dari struktur dan praktik sosial di mana laki-laki pada umumnya bersikap menindas, mengeksploitasi dan mengontrol perempuan, seperti dikemukakan Walby (1990: 21), masih dirasakan oleh perempuan tradisional Hubula Suku Dani, yaitu: dominasi patriarkal tetap berlaku, tetapi eksistensi lakilaki dalam sistem sosial berbasis adat tidak berfungsi lagi. Dominasi patriarkal dan ketidakadilan gender ini ternyata menyebabkan banyak terjadinya kekerasan atas perempuan.
Dalam masyarakat Hubula Suku Dani, kekerasan atas perempuan terjadi ketika suami dan istri sama-sama bersikap kukuh dengan pendiriannya. Di satu sisi, laki-laki mempertahankan dominasi patriarkal berbasis adat dan melakukan praktik yang di mata istri adalah ketidakadilan gender, sedangkan di sisi lain, perempuan mulai cenderung melawan semua jenis tindakan ketidakadilan gender. Di titik konflik atau pertentangan paling tajam ini kekerasan laki-laki atas perempuan sering terjadi yang dilakukan suami pada istrinya. Akibat paling buruk kekerasan laki-laki atas perempuan ini adalah kembalinya istri ke keluarga orangtuanya akibat kekerasan yang dianggap istrinya sudah melampaui batas serta mengancam jiwa, dan ia tidak mau kembali kecuali ditebus dengan babi atau uang sebagai pertanda permintaan maaf suami atas perlakuan keras sebelumnya.

Dalam masyarakat Hubula Suku Dani, kekerasan patriarkal adalah ekspresi maskulinitas di mana laki-laki terdorong emosi seperti kemarahan dan kecemburuan buta (Chowdhury, 2015). Seperti pendapat Hossain dan Sumon (2013), kekerasan perempuan melibatkan makna sosial tertentu dan terjadi dalam hierarki sosial tradisional dan patriarkal. Kekerasan perempuan ini menjadi masalah serius dan dapat mengambil bentuk seperti dominasi, kontrol, intimidasi, tekanan atau bahkan ancaman (Ashcraft, 2000). Korban paling rentan akibat kekerasan domestik laki-laki atas perempuan adalah perempuan itu sendiri. Ketidaksetaraan gender ini mendasari risiko perempuan mengalami ketidakadilan gender yang bermuara pada kekerasan domestik. Seperti dikemukakan oleh Jura dan Bukaliya (2015), kekerasan domestik adalah tindak pelanggaran hukum yang dapat mengakibatkan kematian atau menimbulkan luka fisik, seksual atau mental perempuan.

Pada Gambar 2. menunjukkan bahwa dalam masyarakat Hubula Suku Dani, dominasi patriarkal

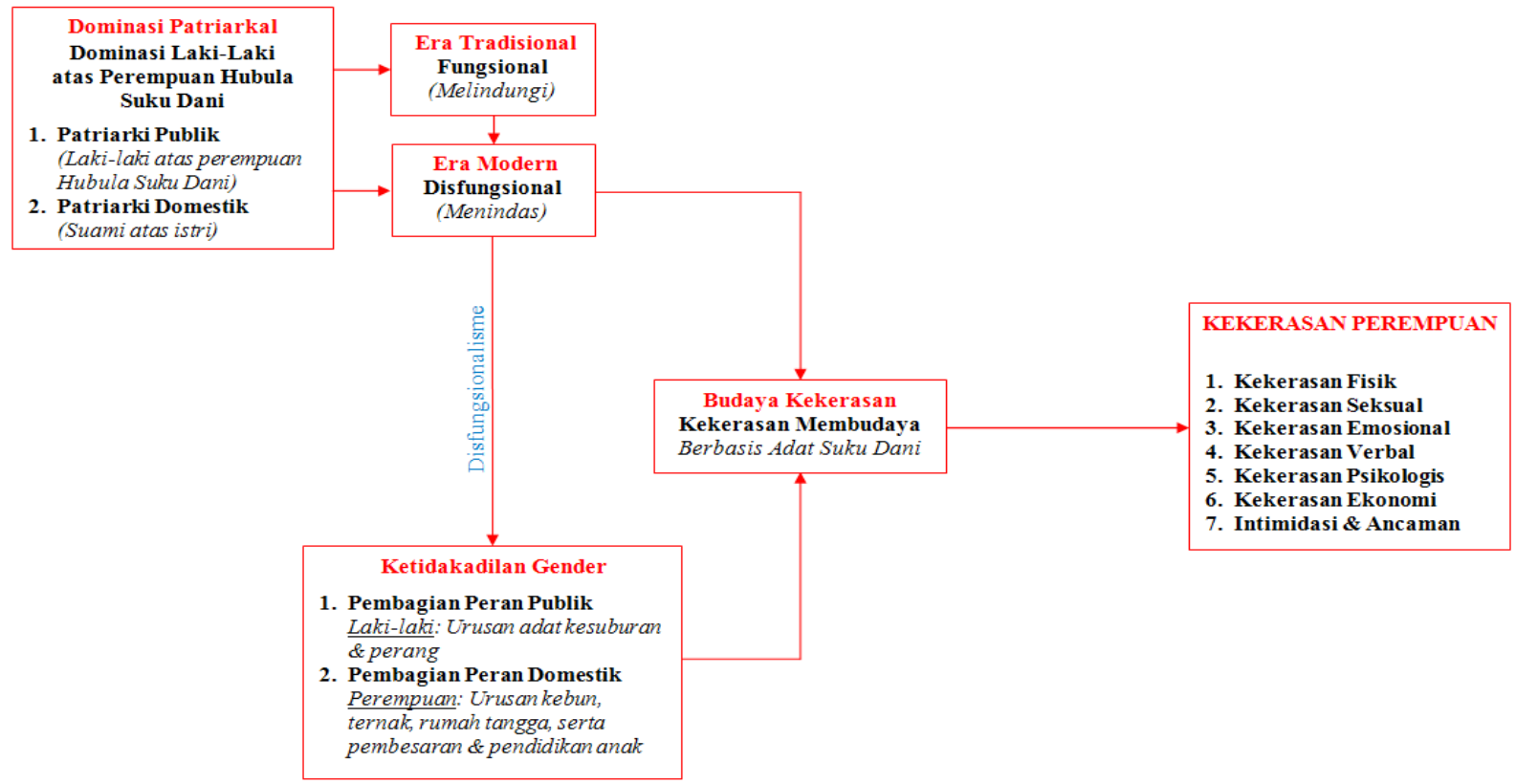

Gambar 2. Dampak Dominasi Patriarkal terhadap Ketidakadilan Gender dan Kekerasan Perempuan 
menyebabkan ketidakadilan gender, yang bermuara pada terjadinya berbagai kekerasan suami atas istri, dari kekerasan fisik, seksual, emosional, verbal, psikologis, ekonomi, sampai intimidasi dan ancaman.

\section{1) Kekerasan Fisik}

Kekerasan fisik adalah tindakan yang menghasilkan rasa sakit, luka, goresan tubuh, pingsan atau kematian. Di masyarakat Hubula Suku Dani, kekerasan fisik oleh suami umumnya terjadi ketika ia memukul istri dengan tangan atau kayu, menghunjam dengan linggis, pisau atau senjata tajam yang lain, menendang keras istri dengan kaki, dan melukai istri dengan senjata tajam (pisau/kampak). Kekerasan fisik sering dilakukan oleh suami dengan berbagai penyebab, terutama karena suami cemburu akibat dugaan istri dekat, main mata atau selingkuh dengan laki-laki lain, ia sedang, sering, atau bahkan terlalu banyak mabuk, atau ia merasa dipermalukan akibat ia menampilkan penentangan terhadap suami, apalagi di depan umum, istri tidak mau berhubungan seks dengan suami karena kecapekan atau sedang mengalami haid, dan lain-lain. Selain itu, suami juga terbiasa mengambil uang simpanan anak sekolah dengan paksa dan jika tidak diperbolehkan oleh istri, ia main pukul. Jika semua kekerasan itu dibiarkan terus berlangsung, dikhawatirkan kelakuan suami akan mengancam nyawa istri.

2) Kekerasan Seksual

Kekerasan seksual mengacu pada tindakan yang membentuk seks paksa, pelecehan seks, seks abnormal dan tidak diinginkan. Bagi perempuan Hubula Suku Dani, kekerasan seksual banyak dirasakan istri karena kerenggangan hubungan seks suami dan istri akibat suami tidak memberi nafkah. Saat masih belum bertanggung jawab sebagai pencari nafkah, suami sering menuntut hubungan seks dalam kondisi istri terlalu capek setelah bekerja seharian penuh dari pagi hingga sore, bahkan malam hari. Bahkan, terjadi juga kekerasan seksual akibat suami memaksa hubungan seks istri saat ia haid. Di luar hubungan rumah tangga, kekerasan seksual bisa terjadi karena pemerkosaan atas calon istri agar perempuan menjadi istri. Akhirnya, ada pelecehan seksual seorang gadis oleh ayah kandungnya sendiri saat istri tidak di rumah. Beberapa kasus kekerasan seksual tersebut pada umumnya terjadi karena suami melihat istri berinteraksi atau berhubungan dengan laki-laki lain, suami cemburu pada istri, istri tidak mau berhubungan seks dengan suami, atau karena dorongan seks tinggi saat suami mabuk.

Jika dikaji secara lebih mendalam, banyak kekerasan suami atas istri dalam masyarakat Hubula Suku Dani berhubungan dengan masalah seksual. Jika suami tahu perselingkuhan yang diduga atau terbukti terjadi pada istri, ia sering mengambil panah dan langsung memanah laki-laki yang dianggapnya menyelingkuhi istridan menimbulkan permusuhan yang sulit diselesaikan. Selain itu, ada dua faktor yang paling banyak menyebabkan kekerasan suami atas istri, yaitu istri tidak mau berhubungan badan dan adanya masalah ekonomi, khususnya ketika tidak ada makanan atau perlengkapan dapur karena suami tidak bekerja dan menelantarkan ekonomi keluarga. Kekerasan seksual terjadi ketika suami menuntut istri berhubungan seks padahal istri sedang sangat capek setelah baru selesai mengerjakan semua urusan rumah tangga, merawat kebun, dan memelihara babi tanpa bantuan suami sama sekali.

3) Kekerasan Emosional

Secara umum kekerasan emosional adalah tindakan yang menimbulkan kejengkelan dan kemarahan tanpa alasan yang jelas. Dalam masyarakat Hubula Suku Dani, suami dengan watak temperamental sering marah-marah terhadap istri tanpa alasan yang jelas, jika diskusi selalu ingin diikuti walau benar atau salah, pembicaraan panjang lebar dan tidak putusputus tapi tidak jelas, dan sebagainya. Kekerasan emosional tersebut sering terjadi karena suami pulang ke rumah tidak disambut oleh istri, istri tidak menyediakan makanan, suami malu akibat kepergok makan padahal tidak bekerja, dan serupa itu. Tindakan tersebut mengindikasikan kekerasan emosional karena tindakan tersebut sering menimbulkan kejengkelan atau kemarahan istri terhadap suami, tetapi istri tidak dapat berbuat apa-apa dan hanya bisa menuruti apa saja kata atau permintaan suami.

Kekerasan emosional terjadi ketika suami selalu saja marah-marah tanpa alasan yang jelas dan jika diajak berdiskusi selalu ingin diikuti, walau benar atau salah. Dalam kondisi ekonomi sulit, suami tidak mau bekerja dan istri saja yang mengurus kebun dan ternak, boleh jadi istri tetap memasak makanan, tetapi suami tidak mau menyentuh makanan itu karena malu. Namun, jika ketahuan mengambil makanan dan istrinya memergokinya, suami merasa tidak nyaman, marahmarah, bicara tidak putus-putus, dan juga tidak jelas apa yang dibicarakan. Emosi suami dan istri selalu tersulut karena apa yang dibicarakan suami selalu tidak sambung dengan apa yang ingin dibicarakan oleh istri, begitu pula sebaliknya.

4) Kekerasan Verbal

Secara umum kekerasan verbal terjadi ketika suami sering bicara keras dan membentak tanpa peduli terhadap lingkungan sekitar. Dalam masyarakat Hubula Suku Dani, kekerasan verbal yang sering dilakukan oleh suami atas memaki-maki istri dengan tuduhan istri telah selingkuh, suami membentak karena istri tidak memenuhi keinginan suami, suami berkata-kata kasar sambil marah tanpa kontrol, istri terlihat main mata atau selingkuh dengan laki-laki lain, istri tidak memenuhi keinginan suami, dan istri tidak melayani suami karena suami tidak bekerja dan akhirnya tidak dapat memberikan nafkah kepada keluarga. Beberapa 
bentuk kekerasan verbal tersebut menyebabkan istri sering merasa sakit hati tetapi mereka tidak mampu berbuat apa-apa karena suami mereka selalu merasa benar dan harus dibenarkan dalam keadaan apa pun, baik benar maupun salah. Jika istri terlihat menentang, suami tidak segan-segan memukul atau menendang istrinya.

Kekerasan verbal terjadi ketika suami sering bicara keras dan membentak tanpa peduli pada lingkungan sekitar. Dalam kondisi marah, kata-katanya sering tidak terkontrol, hawanya ingin menyakiti perasaan istri saja. Jika hal ini terjadi, suami biasanya tidak memberi kesempatan kepada istri untuk bicara, intinya istri harus mendengarkan saja. Jika istri mau menyela, bahkan berani menghentikan pembicaraan suami, maka suami semakin marah, berkata-kata kasar dan bicaranya semakin tidak jelas tanpa kontrol. Apalagi jika istri juga tampil keras dan saling marahmarahan dengan kata-kata yang sama-sama keras, suami cenderung akan mudah melakukan kekerasan, terutama dengan memukul istri. Dengan watak temperamental, suami hampir tidak mungkin mau menerima sikap maupun perilaku istri yang bersifat menentang suami.

5) Kekerasan Psikologis

Secara umum, kekerasan psikologis adalah tindakan suami yang seringkali menimbulkan ketakutan, hilang kepercayaan diri, rasa tidak berdaya dalam diri, hilang kemampuan untuk mengambil tindakan, dan munculnya rasa penderitaan yang serius. Dalam masyarakat Hubula Suku Dani, suami sering sekali menyakiti perasaan istri agar keinginannya terpenuhi apa pun kondisinya, membiarkan istri mengalami dilema pengabaian dan tidak memberikan nafkah selama berbulan-bulan atau bertahun-tahun tanpa ada kabar, suami selalu menuntut istri melayani tetapi ia tidak bekerja sehingga tidak dapat memberikan nafkah, dan suami selalu ingin kawin lagi walau ekonomi belum mencukupi tanpa peduli istri menerima atau tidak. Beberapa jenis kekerasan psikologis tersebut terjadi karena istri tidak segera memenuhi keinginan suami, suami bekerja atau sekolah dan harus pergi ke kota, ke luar daerah, bahkan ke luar pulau yang jauh dalam waktu lama, suami tidak bertanggung jawab tetapi tetap meminta dilayani, dilema karena suami tidak bekerja tetapi selalu pindah-pindah rumah, lalu kawin lagi dan lagi, dan istri harus selalu patuh karena suami sudah memberi mas kawin.

Dalam masyarakat Hubula Suku Dani, kekerasan psikologis terjadi pada saat suami dengan sengaja menyakiti istri agar kepentingannya terpenuhi tanpa mempertimbangkan perasaan istri sama sekali. Kekerasan ini terjadi jika suami membiarkan istri mengalami dilema tanpa pilihan yang jelas. Di satu sisi, suami harus selalu dituruti sesuai dengan aturan adat atau kebiasaan dominasi patriarki, sedangkan di sisi lain, istri pada dasarnya paham bahwa sikap dan perilaku suaminya salah tanpa bisa bicara. Apalagi jika suami enggan bekerja di kebun, tidak terlibat mengurus ternak, tidak membantu mengurus rumah tangga. Dilema biasanya juga terjadi jika suami ingin kawin lagi walaupun sebenarnya kebutuhan ekonomi keluarga belum tercukupi. Kekerasan psikologis selalu menimbulkan dilema karena suami berpendapat ia telah membeli istri dengan mas kawin yang pernah diberikannya dan istri harus senantiasa patuh serta menghormati suami dalam keadaan apa pun, walau suami sering melakukan tindak kekerasan kepadanya setiap hari.

6) Kekerasan Ekonomi

Secara umum kekerasan ekonomi merupakan tindakan yang menimbulkan kerugian ekonomi, tercabutnya hak ekonomi anggota keluarga, tidak memberikan nafkah dan mengabaikan anggota keluarga. Dalam masyarakat Hubula Suku Dani, kekerasan ekonomi sering terjadi akibat suami tidak dapat memenuhi kebutuhan ekonomi keluarga, suami mengambil simpanan uang sekolah untuk mabuk, suami tidak bekerja dan tidak mampu memberikan nafkah dengan baik, suami memaksa istri memberikan makanan walaupun tidak ada, suami menghabiskan uang dalam acara-acara adat, suami memakai uang untuk mabuk atau bermain perempuan, suami melarang istri bekerja untuk mencari pendapatan tambahan, suami tidak memberikan nafkah dalam waktu lama, dan suami tidak mampu membangun rumah dan membiayai sekolah anak-anak. Beberapa masalah kekerasan ekonomi sering sekali terjadi karena pada umumnya suami tidak bekerja dan tidak memiliki pendapatan yang memadai sebagai nafkah keluarga, suami tidak mau bekerja dan melarang istri bekerja di luar rumah, suami memangkas akses dan kontrol strategis istri atas pendapatan, suami ingin mabuk-mabukan atau main perempuan atau kawin lagi dan lagi, suami pergi keluyuran ke kota tanpa ada tujuan dan hasil kerja yang jelas, dan suami mengabaikan keluarga dalam waktu lama.

Beberapa fenomena yang ditemukan di lapangan tersebut mengindikasikan bahwa kekerasan ekonomi sering terjadi pada saat kebutuhan ekonomi keluarga tidak dapat terpenuhi karena suami tidak memiliki pekerjaan dengan pendapatan yang memadai atau suami tidak mau bekerja di kebun. Dalam hal ini, suami selalu memaksakan kepada istri agar makanan selalu tersedia di rumah sewaktu-waktu ia datang, padahal di rumah tidak ada makanan dan uang akibat suami menganggur, bermalas-malasan, atau mabuk-mabukan. Lebih parah, dalam kondisi suami tidak mempunyai pekerjaan, tidak mau bekerja di kebun, dan tidak memiliki makanan, pekerjaan suami hanyalah marah-marah dan menyalahkan istri karena tidak ada makanan tersedia di rumah. Akibat terburuk 
dari kekerasan yang dilakukan oleh suami seperti itu adalah kelelahan istri yang amat sangat akibat ia harus mengolah dan menanami kebunnya sendiri, memelihara ternak sendiri, dan mengurus rumah tangga sendiri, bahkan ia sering terpaksa harus mencuri hasil kebun milik tetangga akibat di rumahnya tidak tersedia makanan, yang berakibat suaminya memukuli dirinya karena merasa malu ketahuan orang.

7) Intimidasi dan Ancaman

Secara umum intimidasi dan ancaman seringkali terjadi sebagai tindakan suami menekan istri agar ia memenuhi kebutuhan suami dan tidak menyinggung suami. Dalam masyarakat Hubula Suku Dani, intimidasi dan ancaman oleh laki-laki atas perempuan terjadi sesuai adat karena istri harus selalu patuh pada suami dalam kondisi apa pun, baik benar maupun salah. Intimidasi dan ancaman sering terjadi pula ketika suami dalam suatu konflik menekan istri agar ia tidak pulang ke rumah orangtuanya apalagi dalam waktu lama dan tidak mau kembali lagi jika suami tidak datang menjemput dengan membawa babi sebagai tebusan dan tanda permintaan maaf. Ketika terjadi kecemburuan, suami juga biasanya mengancam istri agar ia tidak banyak dan terlalu lama keluar rumah serta berhubungan dengan laki-laki lain. Suami juga biasa mengancam istri agar ia tidak menyimpan rahasia tentang pacar baru atau selingkuhan baru, walau ketika rahasia sudah dibongkar, suami menjadi marah dan memaki-maki serta memukul istri. Semua kekerasan itu umumnya terjadi karena suami merasa sudah menguasai istri lantaran dulu sudah memberikan mas kawin kepada istri. Suami juga merasa kaya sehingga ia mampu membayar apa pun dalam jumlah berapa pun asalkan masalahnya dengan istri bisa selesai, atau suami memiliki banyak istri sehingga ia merasa bebas berbuat apa saja tanpa merasa khawatir satu atau lebih istrinya kabur atau berpisah, atau suami memiliki banyak babi untuk tebusan bila istri pulang ke rumah akibat konflik dan kekerasan oleh suami. Selain itu, kekerasan berupa intimidasi dan ancaman sering terjadi karena suami memiliki watak temperamental, yang sangat emosional, mudah marah, dan selalu curiga pada istri. Akhirnya, disadari atau tidak, istri cenderung patuh kepada suami, atau lebih tepatnya menurut saja apa kemauan suami, walaupun sudah banyak sikap dan tindakan kekerasan ia alami dari suaminya karena gereja mendorong istri patuh walaupun suami tidak bekerja, tidak memberikan nafkah, dan sering melakukan berbagai kekerasan. Intimidasi dan ancaman terjadi ketika suami menekan istrinya agar ia tidak sampai melakukan sesuatu yang menyebabkan suami sampai tersinggung.

Pembagian peran yang tidak adil, yang sering terjadi antara laki-laki dan perempuan Hubula Suku Dani dan pada akhirnya bermuara pada kekerasan perempuan, pada dasarnya tidak terlepas dari pengaruh budaya atau adat-istiadat Hubula Suku Dani, sehingga perempuan tidak bisa melawan atau pun negosiasi. Biasanya laki-laki akan berkata, "Ini adat. Ko harus kerja, ko harus terima, ko harus pikul." Tradisi adat dalam masyarakat Hubula Suku Dani inilah yang pada akhirnya menjadi sumber utama terjadinya kekerasan laki-laki atas perempuan karena adat ternyata lebih banyak mengintimidasi istri supaya mereka selalu melakukan apa pun yang disuruh oleh suaminya.

Tabel 2. Ringkasan Temuan Penelitian tentang Kekerasan atas Perempuan Hubula Suku Dani Beserta Penyebab Umumnya (2018)

\begin{tabular}{|c|c|c|c|}
\hline No. & Indikator & Tindakan Kekerasan Laki-Laki & Penyebab Umum \\
\hline 1. & $\begin{array}{l}\text { Kekerasan Fisik } \\
\text { Tindakan yang } \\
\text { menghasilkan rasa sakit, } \\
\text { luka, goresan tubuh, } \\
\text { pingsan atau kematian }\end{array}$ & $\begin{array}{l}\text { - Memukul istri dengan tangan atau kayu } \\
\text { - Menghuncam dengan linggis atau pisau. } \\
\text { - Menendang keras istri dengan kaki } \\
\text { - Melukai istri dengan senjata tajam (pisau/ } \\
\text { kampak) }\end{array}$ & $\begin{array}{l}\text { - Cemburu akibat dugaan istri selingkuh dengan } \\
\text { laki-laki lain } \\
\text { - Sedang, sering atau banyak mabuk } \\
\text { - Malu akibat penentangan istri di depan umum } \\
\text { - Istri tidak mau hubungan seks dengan suami }\end{array}$ \\
\hline 2. & $\begin{array}{l}\text { Kekerasan Seksual } \\
\text { Tindakan yang membentuk } \\
\text { seks paksa, pelecehan } \\
\text { seksual, seks abnormal dan } \\
\text { tidak diinginkan }\end{array}$ & $\begin{array}{l}\text { - Tuntutan hubungan seks dalam kondisi istri } \\
\text { capek } \\
\text { - Pemaksaan hubungan seks saat istri sedang haid } \\
\text { - Pemerkosaan calon istri agar perempuan jadi istri } \\
\text { - Pelecehan seksual putrinya saat istri tidak di } \\
\text { rumah }\end{array}$ & $\begin{array}{l}\text { - Istri berinteraksi atau berhubungan dengan laki- } \\
\text { laki lain } \\
\text { - Istri tidak mau berhubungan seks dengan suami } \\
\text { - Istri tidak menyediakan makanan di rumah } \\
\text { - Dorongan seksual tinggi saat mabuk }\end{array}$ \\
\hline 3. & $\begin{array}{l}\text { Kekerasan Emosional } \\
\text { Tindakan yang menimbulkan } \\
\text { kejengkelan dan kemarahan } \\
\text { tanpa alasan yang jelas }\end{array}$ & $\begin{array}{l}\text { - Marah-marah tanpa alasan yang jelas } \\
\text { - Jika diskusi selalu ingin diikuti, benar atau } \\
\text { salah } \\
\text { - Pembicaraan tidak putus-putus dan tidak jelas }\end{array}$ & $\begin{array}{l}\text { - Suami pulang tidak disambut } \\
\text { - Istri tidak menyediakan makanan } \\
\text { - Suami malu karena kepergok makan padahal } \\
\text { tidak bekerja }\end{array}$ \\
\hline 4. & $\begin{array}{l}\text { Kekerasan Verbal } \\
\text { Bicara keras dan } \\
\text { membentak tanpa peduli } \\
\text { pada lingkungan sekitar }\end{array}$ & $\begin{array}{l}\text { - Makian suami dengan tuduhan istri telah selingkuh } \\
\text { - Bentakan karena istri tidak penuhi keinginan suami } \\
\text { - Berkata-kata kasar sambil marah tanpa kontrol }\end{array}$ & $\begin{array}{l}\text { - Istri terlihat main mata atau selingkuh dengan laki- } \\
\text { laki lain } \\
\text { - Istri tidak memenuhi keinginan suami } \\
\text { - Istri tidak melayani suami karena suami tidak bekerja }\end{array}$ \\
\hline 5. & $\begin{array}{l}\text { Kekerasan Psikologis } \\
\text { Menimbulkan ketakutan, } \\
\text { hilang kepercayaan, } \\
\text { rasa tak berdaya, hilang } \\
\text { kemampuan ambil tin- } \\
\text { dakan, dan penderitaan } \\
\text { serius }\end{array}$ & $\begin{array}{l}\text { - Menyakiti perasaan istri agar keinginan } \\
\text { terpenuhi } \\
\text { - Membiarkan istri mengalami dilema pengabaian } \\
\text { - Menuntut istri melayani tapi suami tidak bekerja } \\
\text { - Ingin kawin lagi walau ekonomi belum } \\
\text { mencukupi }\end{array}$ & $\begin{array}{l}\text { - Suami kerja atau sekolah dan harus pergi jauh lama } \\
\text { - Suami tidak bertanggung jawab tapi tetap minta } \\
\text { dilayani } \\
\text { - Dilema karena suami tidak bekerja tapi kawin lagi } \\
\text { dan lagi } \\
\text { - Istri harus patuh karena suami sudah memberi mas } \\
\text { kawin }\end{array}$ \\
\hline
\end{tabular}

Relasi Gender Patriarki Dan Dampaknya Terhadap Perempuan Hubula Suku Dani, Kabupaten Jayawijaya, Papua

(Yanuarius You., Enos H. Rusmansara., Johz Mansoben dan Agustina Ivone Poli) 


\begin{tabular}{lll}
\hline 6. Kekerasan Ekonomi & - Tidak memenuhi kebutuhan ekonomi keluarga & - Suami tidak bekerja dan tidak punya pendapatan \\
Tindakan yang & - Mengambil simpanan uang sekolah untuk mabuk & memadai \\
menimbulkan kerugian & - Tidak bekerja dan tidak bisa memberikan nafkah & - Suami tidak mau bekerja dan melarang istri bekerja \\
ekonomi, tercabutnya hak & - Memaksa istri memberi makanan walau tidak ada & di luar \\
ekonomi anggota keluarga, & - Menghabiskan uang dalam acara-acara adat & - Suami memangkas akses dan kontrol atas pendapatan \\
tidak memberikan nafkah, & - Memakai uang untuk mabuk atau main & - Suami tetap ingin mabuk, main perempuan atau kawin \\
dan mengabaikan anggota & perempuan & lagi \\
keluarga & - Melarang istri bekerja untuk pendapatan & - Suami pergi jauh ke kota tanpa tujuan dan hasil yang \\
& tambahan & jelas \\
& - Tidak memberikan nafkah dalam waktu lama & - Suami mengabaikan keluarga dalam waktu lama \\
Intimidasi dan Ancaman & - Intimidasi adat agar istri selalu patuh pada suami & - Rasa menguasai istri karena sudah memberikan mas \\
Tindakan menekan & - Menekan istri agar tidak pulang ke rumah & kawin \\
istri agar ia memenuhi & orangtua & - Merasa kaya, banyak istri, dan banyak babi untuk \\
kebutuhan suami dan tidak & - Ancam istri tidak berhubungan dengan laki-laki & tebusan \\
menyinggung suami & lain & - Emosional, mudah marah, dan selalu curiga pada istri \\
& - Ancam istri agar tidak simpan rahasia pacar baru & - Gereja mendorong istri patuh, tapi suami tidak bekerja \\
\hline
\end{tabular}

Sumber: Data primer diolah (2018)

Seiring berkurangnya signifikasi aturan adat bagi laki-laki Hubula Suku Dani, semakin besar kemungkinan laki-laki menyalahgunakan otoritas adat untuk melakukan kekerasan domestik. Tendensi ini seperti dikemukakan Jura dan Bukaliya (2015) bahwa kekerasan domestik terjadi karena adanya penyalahgunaan kekuasaan dalam hubungan suami dan istri yang terjadi akibat pemaksaan kendali fisik, verbal, seksual, psikologis, dan emosional. Dalam masyarakat Hubula Suku Dani, sebagian besar atau hampir semua laki-laki mempunyai tendensi yang sama untuk menerapkan praktik dominasi patriarkal dan melakukan kekerasan atas perempuan. Artinya, kebiasaan atau bahkan tradisi patriarki sudah benar-benar membudaya di kalangan laki-laki tradisional Hubula Suku Dani sehingga istri-istri yang sudah merasakan sakitnya dominasi patriarki dan kekerasan laki-laki atas perempuan umumnya tidak kuasa lagi berpikir berpisah dari suami lamakarena ke mana pun mereka pergi dan mencari lakilaki lain, suami mereka cenderung akan memiliki watak, karakteristik, sikap dan perilaku yang serupa: dominan dan keras.

Dominasi patriarkal dan kekerasan suami atas istri tersebut membudaya di dalam Hubula Suku Dani. Seperti dikemukakan Jura dan Bukaliya (2015), jika perilaku kekerasan itu berulang dalam siklus tanpa intervensi apa pun, kekerasan domestik boleh jadi lepas kendali dan meluas keluar dinding rumah tangga dan membudaya dalam masyarakat lebih luas. Di masyarakat Hubula Suku Dani, kecenderungan ini kentara. Walau mengalami kekerasan verbal, seksual, psikologis, emosional dan fisik, istri sering terpaksa memilih bertahan sampai anak besar dan sudah bisa membantunya menggantikan suami sebagai pencari nafkah secara optimal.

Banyak keluarga Hubula Suku Dani memiliki satu atau paling banyak dua anak. Jika istri melahirkan anak pertama, ia enggan memiliki anak kedua. Bagi mereka, menjadi istri adalah tugas berat karena laki-laki Hubula tak mau bekerja di kebun, memelihara ternak, dan mengurus rumah tangga. Semua pekerjaan itu dilakukan istri. Kondisi paling memprihatinkan adalah saat istri hamil, suami tidak berubah, bahkan membiarkan atau mengharuskan istri tetap bekerja sendiri. Fenomena ini menunjukkan pengabaian istri pada saat genting kehamilan sudah menjadi tradisi atau "budaya" di kalangan lakilaki Hubula Suku Dani. Inilah penyebab paling utama keengganan istri untuk beranak lebih dari satu dan suami tidak dapat memaksakan diri kepada istrinya. Anehnya, setiap kali istri menolak setiap kali suami meminta hubungan seks, ia mulai berani menolak karena mereka tidak mau lagi mengalami penderitaan berat selama hamil dan setelah anak lahir akibat beban peran ganda, bahkan peran majemuk, dalam rumah tangga tradisional Hubula Suku Dani.

Dengan terjadinya kekerasan suami atas istri selama bertahun-tahun, para istri dari masyarakat Hubula Suku Dani pada umumnya mengalami penderitaan dalam keluarga. Tidak sedikit perempuan Hubula Suku Dani yang sudah menikah mengalami kekerasan fisik yang ditandai dengan goresan atau luka dan rasa sakit yang dalam. Awalnya istri yang mulai mengalami kekerasan dari suami merasa takut, tidak percaya diri, tidak berdaya serta tidak berani mengambil sikap dan tindakan dalam menghadapi suami yang sering melakukan kekerasan. Mereka juga sering mengalami perkosaan dalam perkawinan akibat tindakan apa pun yang dilakukan oleh suami dan akhirnya menyebabkan terjadinya hubungan seks paksa dan tidak diinginkan, khususnya pada saat istri sedang terlalu capek akibat beban majemuk yang dipikulnya dan tidak ingin memiliki anak lagi.

Temuanpenelitianinimenunjukkanbahwakekerasan domestik suami atas istrinya ternyata membudaya dalam masyarakat Hubula Suku Dani. Kekerasan fisik, ekonomi, emosional, psikologis, verbal dan seksual suami atas istri menjadi masalah yang berakar mendalam sebagai masalah sosial dan budaya (Ostadhashemi, et al., 2015). Masalah ini mengancam kualitas hidup perempuan dalam rumah tangga. Kekerasan suami atas istri ini terjadi di ranah privasi (Ostadhashemi, et al., 2015). Ketidakadilan gender ini berakar dalam kondisi ketidakseimbangan kekuasaan dan hubungan struktural yang tidak setara antara laki-laki dan perempuan, sedangkan istri tidak berdaya melakukan pembebasan dari subordinasi pada laki-laki Hubula Suku Dani. 


\section{SIMPULAN}

Masyarakat Hubula Suku Dani menganut sistem sosial patriarki dan sejak lama membedakan posisi, otoritas dan peran laki-laki dan perempuan di ruang publik dan keluarga. Mereka menempatkan perempuan dalam subordinasi perempuan di bawah dominasi laki-laki. Pada saat suami tidak lagi berperan fungsional sebagai pencari nafkah, ketidakadilan gender terjadi. Suami tidak melaksanakan fungsi sebagai pencari nafkah tetapi ia berdasarkan adat tetap memaksakan kemauan agar istri melaksanakan kewajiban melayani, termasuk memenuhi kebutuhan seks. Berbagai kekerasan laki-laki atas perempuan dalam masyarakat Hubula Suku Dani terjadi secara merata atau membudaya di tengah kehidupan masyarakat dengan sistem dominasi patriarkal yang tidak lagi fungsional dan bermuara pada ketidakadilan gender.

\section{DAFTAR PUSTAKA}

Ashcraft, C. (2000) Naming knowledge: A Language for Reconstructing Domestic Violence and Systemic Gender Inequity. Women and Language, 23, (1), 3-10

Chaitali, D. (2012) Barriers and Supports to Divorce for Victimised British- Indian Mothers and Consequences of Divorce: Narratives of BritishIndian Adult Children of Divorce. Child Care in Practice, 18, (2), 147-164.

Chapman, R. \& Rutherford, J. (2014) Male Order: Menguak Maskulinitas, Yogyakarta: Jalasutra

Chowdhury, E.H. (2015) Rethinking Patriarchy, Culture and Masculinity: Transnational Narratives of Gender Violence and Human Rights Advocacy. Journal of International Women's Studies, 16, (2), 98-114.

Cepos (Cenderawasih Pos), 28 Nopember 2017, Kekerasan Perempuan di Papua, hal. 1

Djamba, Y.K. \& Kimuna, S.R. (eds.) (2015) GenderBased Violence: Perspectives from Africa, the Middle East, and India, Switzerland: Springer International Publishing.

Fakih, M. (1996) Analisis Gender dan Transformasi Sosial, Yogyakarta: Pustaka Pelajar.

Gheaus, A. (2012) Gender Justice, Journal of ethics \& social philosophy. 6, (1),1-24.

Giuliano, P. (2014) The Role of Women in Society: from Preindustrial to Modern Times, CESifo Economic Studies, 61, (1), 33-53

Habiba, U., Ali, R., \& Ashfaq, A. (2016) From Patriarchy to Neopatriarchy: Experiences of Women from Pakistan, International Journal of Humanities and Social Science. 6, (3), 212-221.
Hossain, K.T. \& Sumon, M.S.R. (2013) Violence against Women: Nature, Causes and Dimensions in Contemporary Bangladesh, Bangladesh e-Journal of Sociology. 10, (1), 79-91.

Hoven (2001) Domestic violence in South Africa. Acta Criminologica, 14, (3), 13-25

Isran, S. \& Isran, M.A. (2012) Patriarchy And Women In Pakistan: A Critical Analysis, Interdisciplinary Journal of Contemporary Research In Business, 4, (6), 835-859

Jansson, P.M. (2017) An Explorative Integration of Factors Causing Men's Violence against Women. Journal of Psychology and Clinical Psychiatry, 8, (2), 2-11. https://doi.org/10.15406/ jpcpy.2017.8.00475

Johnson, M. (1995) Patriarchal terrorism and common couple violence: two forms of violence against women. Journal of Marriage \& the Family, 57, (2), 283-294.

Jura, F. \& Bukaliya, R. (2015) "Domestic Violence: Causes and Implications for the Education System", International Journal of Research in Humanities and Social Studies, 2, (4), 62-72.

Knoblock, J. (2008) Gender and Violence: A Reflective Sociology of How Gender Ideologies and Practices Contribute to Gender Based Violence, Human Architecture: Journal of the Sociology of Self-Knowledge: 6, (2), 91-102.

Mashiri, L. (2013) Conceptualisation of Gender Based Violence in Zimbabwe, International Journal of Humanities and Social Science, 3, (15), 94-103.

Miles, M.B. \& Huberman, M.A. (2009) Analisis Data Kualitatif, Penerjemah: Rohidi Tjetjep Rohendi, Jakarta: Universitas Indonesia.

Mtshiselwa, N. (2015) 'Reconstructing a Deuteronomistic Athaliah in the (South) African context: A critique of the patriarchal perception of women', Verbum et Ecclesia, 36, (1), 1-8.

Muthali'in. (2001) Bias Gender Dalam Pendidikan, Surakarta: Universitas Muhammadiyah Surakarta.

Njezula, A.B. (2006) Investigating Domestic Violence against Women in South Africa, Dissertation, Department of Statistics, Estern Cape: University of the Western Cape.

Ostadhashemi L, Khalvati M, Seyedsalehi M, \& Emamhadi M. (2015) A Study of Domestic Violence against Women: A Qualitative Meta-Synthesis. International Journal of Medical Toxicology and Forensic Medicine; 5, (3), 155-163.

Parker, K.F. \& Reckdenwald, A. (2008) Women and Crime in Context Examining the Linkages 
Between Patriarchy and Female Offending Across Space. Feminist Criminology, 3, (1), 5-24.

Suryadi \& Idris (2004) Kesetaraan Gender Dalam Bidang Pendidikan, Bandung: Genesindo.

Sylvana M.A. (Ed.), (2015), Anyan Noken Kehidupan: Papua TanahDamai MenurutPerempuan Penyintas Kekerasan \& Pembela HAM, Kerjasama: Komisi Nasional Anti Kekerasan terhadap Perempuan, Jaringan Kerja HAM Perempuan Papua Tiki, Majelis Rakyat Papua 2012-2014, Jakarta: Komisi Nasional Anti Kekerasan Terhadap Perempuan.
Walby, S. (1990) Teorizing Patriarchy, Oxford: Basil Blackwell.

WHO. (2009) Violence Prevence: the Evidence (Promoting Gender Equality to Prevent Violence against Women), World Health Organization.

Yodanis, C.L. (2004) Gender inequality, violence against women, and fear: a cross-national test of the feminist theory of violence against women. Journal of Interpersonal Violence, 19, 655-675. 